\title{
I I Cistercian architecture or architecture of the Cistercians?
}

\author{
THOMAS COOMANS
}

Architecture is, without a doubt, the most tangible witness to the medieval Cistercian legacy. Not only standing churches and cloisters, but abbey ruins and rural granges also attract several million visitors yearly; special routes and networks of Cistercian abbeys may be found across Europe, and no less than five abbeys have been inscribed on the UNESCO World Heritage list. ${ }^{\mathrm{I}}$ Cistercian architecture is a popular subject - attractive to tourists, fascinating to scholars and a niche for publishers. This chapter contains four complementary approaches to the subject. After sketching the main historiographical steps of past and present research, I shall examine the central issue of the architectural specificity or identity of medieval Cistercian abbeys, then consider the abbey buildings as a material source for monastic life and finally define major research perspectives.

\section{HISTORIOGRAPHY}

In his famous Dictionnaire (I 854) Eugène Viollet-le-Duc, as one of the first scholars, stressed the specificity of Cistercian architecture by analysing the plans of Clairvaux and Cîteaux, the churches of Fontenay and Pontigny, the cloisters of Thoronet and Fontfroide and the infirmary of Ourscamp. ${ }^{2}$ This was the source for a long line of scholars who were to consider Cistercian architecture in the first instance as a product of the Romanesque period, originating in Burgundy, intimately related to Bernard of Clairvaux, spreading internationally through the network of the Order and controlled by its General Chapter. Edmund Sharpe, author of the first book dedicated entirely to Cistercian architecture (1874), ${ }^{3}$ focused on the buildings of the White Monks in an international and comparative perspective. Contemporaneous authors considered it as part of a national style. In the increasingly nationalistic climate preceding the First World War, authors such as Camille Enlart depicted the medieval Cistercians as 'missionaries' of an early Gothic canon to Italy, 
Scandinavia, Poland and other countries. ${ }^{4}$ Inversely, British and German scholars, refusing the theory of a pure French export, tried to prove how Cistercian architecture was indigenous to their respective countries. To this end they employed different rational and positivist methods. Art historians made architectural parallels, comparing series of church plans on the same scale to show similarities and differences, and to define evolution and geographic groups. ${ }^{5}$ In parallel fashion archaeologists began to study buildings and to excavate ruined sites, bringing to light material evidence of abbey layouts and publishing the first series of monographs. The outstanding work done by William St John Hope from the I 870 s can be considered the birth of monastic archaeology, an expertise that remains prominent in British scholarship. ${ }^{6}$

The monastic revival that developed in Europe from the last decades of the nineteenth century attempted to restore authentic monastic life on the basis of new knowledge of both liturgy and architecture. From then on several generations of French, Belgian, German and Italian Cistercian 'monk-scholars' were particularly active and produced high-level scholarship into the I970s.7 During the period between the two World Wars lay scholars had other priorities. Therefore the two volumes on Cistercian architecture in France (I943) by Marcel Aubert and the marquise de Maillé are a milestone, not only because they provide a synthesis, but also because they include monastic and ancillary buildings as well as abbeys of Cistercian women. ${ }^{8}$ After the Second World War, the I953 commemorations of the death of Bernard of Clairvaux (I I53) gave a boost to the study of Cistercian architecture. French and German scholars accepted the concept of 'Bernardine' church layout as defined by Karl-Heinz Esser, ${ }^{9}$ and the standard works by Father Anselme Dimier and Georges Duby greatly contributed to the diffusion of the so-called Bernadine paradigm. ${ }^{\text {Io }}$ Literary fictions and illustrated publications popularised this architectural stereotype. ${ }^{\text {II }}$

The I980s and I990s could be considered the 'golden age' of Cistercian architectural studies. Important exhibitions in Aachen (I980) and Paris (I990), ${ }^{\mathrm{I} 2}$ international Cistercian celebrations in 1990 and I998, numerous conferences and workshops, the promotion of five abbeys to World Heritage status, the multiplication of excavation campaigns and other studies considerably broadened the field of research in time and space. New series were launched, such as Studies in Cistercian Art and Architecture, ${ }^{13}$ and special sessions on Cistercian architecture organised at the annual congresses for medieval studies at Kalamazoo and Leeds. Scholars began working on Cistercian Gothic architecture, ${ }^{14}$ granges and rural space, ${ }^{15}$ mills and hydraulic works ${ }^{16}$ and decorative 
arts related to architecture (grisaille windows, patterned floor tiles, wall paintings and so forth). The British tradition of monastic archaeology, combined with building as well as landscape archaeology, reached high levels at Fountains and Bordesley and generated several excellent synthetic publications. ${ }^{17}$ Elsewhere, high-quality architectural monographs integrated a broad range of sources and combining different methods. ${ }^{18}$ After I989 the Cistercian heritage of central Europe received new attention and regional studies began to appear, such as brick architecture of the abbeys in the Baltic area. ${ }^{\text {I9 }}$

After the proliferation of publications leading up to the nine-hundredth anniversary of the foundation of Cîteaux Abbey in 1998, the acquisition of new information and acknowledgement of the complexity and diversity of Cistercian architecture led to synthetic works, the best amongst which are those by Terryl N. Kinder and Matthias Untermann. ${ }^{20}$ The most recent developments look at Cistercian architecture through the lenses of anthropology, gender, funerary spaces and the environment. ${ }^{2 I}$ These are part of the current interest in the Order and try to overcome the earlier tendency of isolating the Cistercian contribution from the broader field of monastic (and non-monastic) architecture.

\section{ARCHITECTURE AND CISTERCIAN IDENTITY}

The Cistercian Order was not created ex nihilo but developed as a reform of the Benedictine Cluniacs, motivated by the desire to return to the original spirit of austerity and poverty of the Rule of Benedict. Cistercians thus never rejected the monastic tradition but did reform the components of monastic life according to what they called the forma Ordinis, a general term referring to the exterior forms of Cistercian practice such as behaviour, habits, diet and buildings. There is, however, no written explanation that defines an architectural norm, only some decisions made by the General Chapter which condemned buildings that did not conform to the forma Ordinis. ${ }^{22}$ The statutes do nevertheless specify that 'all unnecessary new things and notable curiosities' (omnes superfluae novitates et notabiles curiositates) were to be rejected, and this interdiction included towers, ornate pavements, coloured glass windows, paintings, sculpture, crosses, bells, images (except that of Christ) and ornaments. Since the legislation repeated these interdictions until the end of the thirteenth century, it would appear that the norm was not always respected.

The most important sources are the buildings themselves. Despite the destruction of many pivotal abbey churches - including those of 


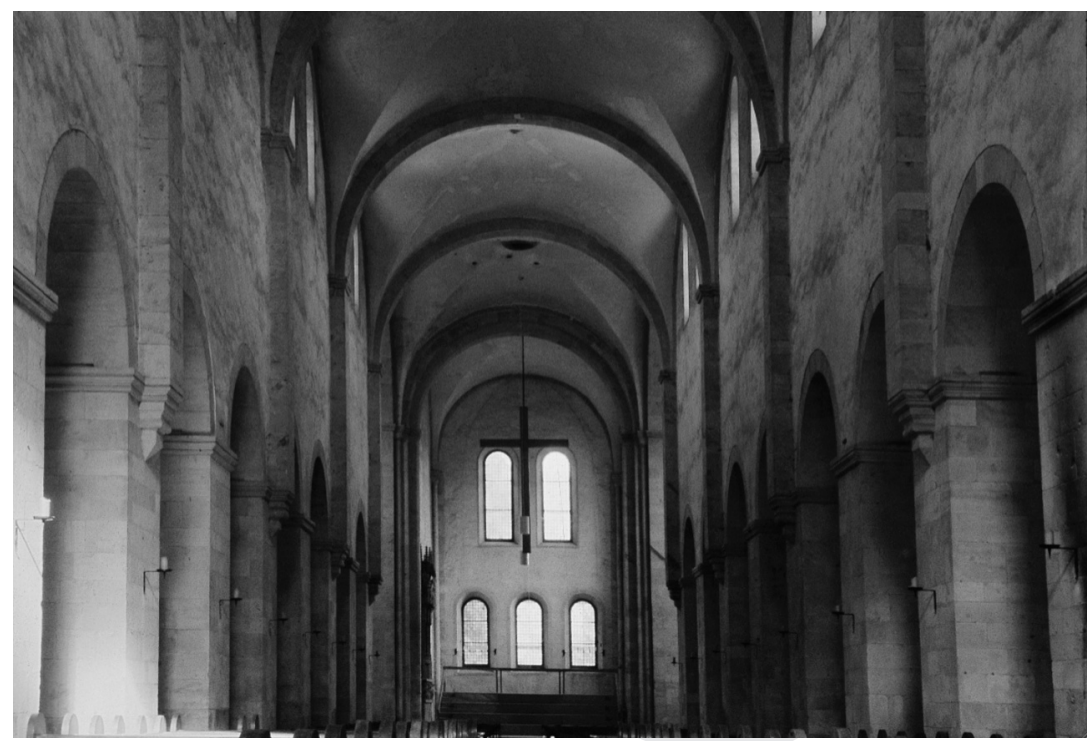

Figure I I.I Eberbach (Germany), interior of the abbey church to the choir, photo: Thomas Coomans, (c) THOC-SOFAM.

the mother houses of Cîteaux, Clairvaux, Morimond and La Ferté - as well as the difficulty of dating most medieval buildings with accuracy, it is only possible to understand the meaning of forma Ordinis by comparing Cistercian churches to architecture outside the Order, especially that of twelfth-century Benedictine monasteries. For Cistercians austerity meant simplicity of design, structure and decoration, the functional essence. The character of Cistercian churches results from a combination of geometric proportions, pure forms, high-quality stone carving, good acoustics and light (Figure II.I). This material harmony framed an equally simplified liturgy and sought to trace a path leading without distraction to contemplation and ultimately to God. The forma Ordinis is certainly not a style but rather a spirit that can be found in buildings of different periods, locations, scales, functions, materials, details and even styles. Contextualisation is therefore indispensable in order to understand Cistercian architecture and to appreciate the differences and similarities inherent in the formula 'unity and diversity' exemplified in the contemporaneous twelfth-century abbey churches of Fontenay and Pontigny, both in Burgundy (Figure II.2 and Figure II.3); the twelfthand thirteenth-century building campaigns of the churches at Fountains and Ourscamp; or the Romanesque ashlar masonry at Sénanque and the Gothic brick architecture at Løgum. Just as with illumination and 


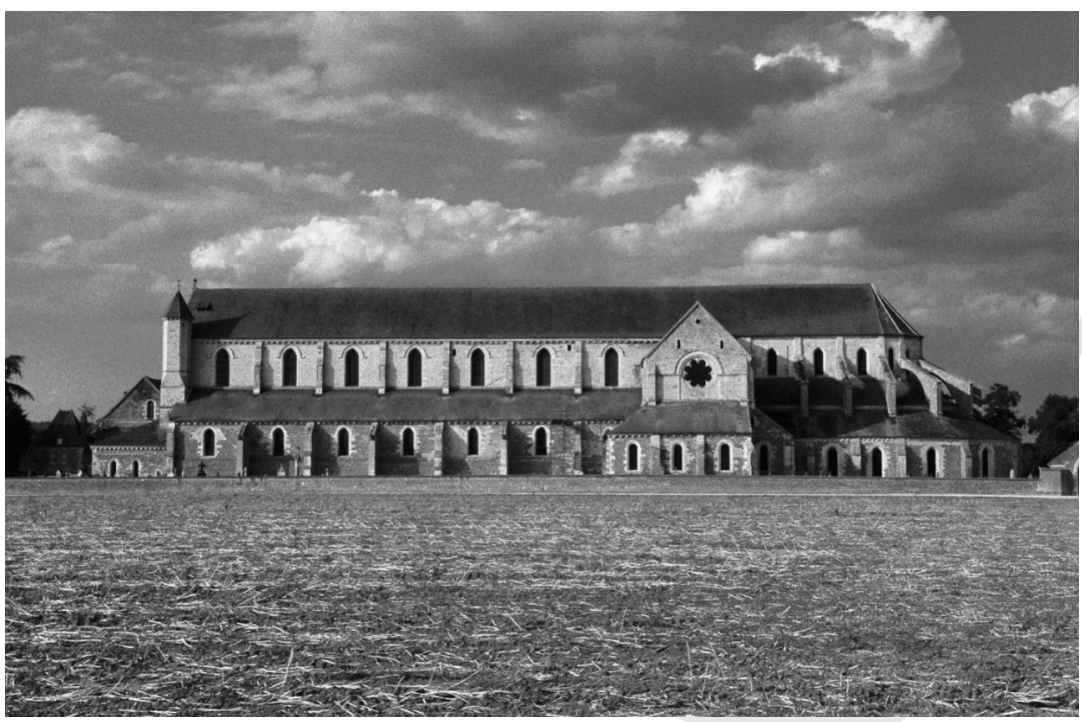

Figure I I.2 Pontigny (France), abbey church seen from the south, photo: Thomas Coomans, (C) THOC-SOFAM.

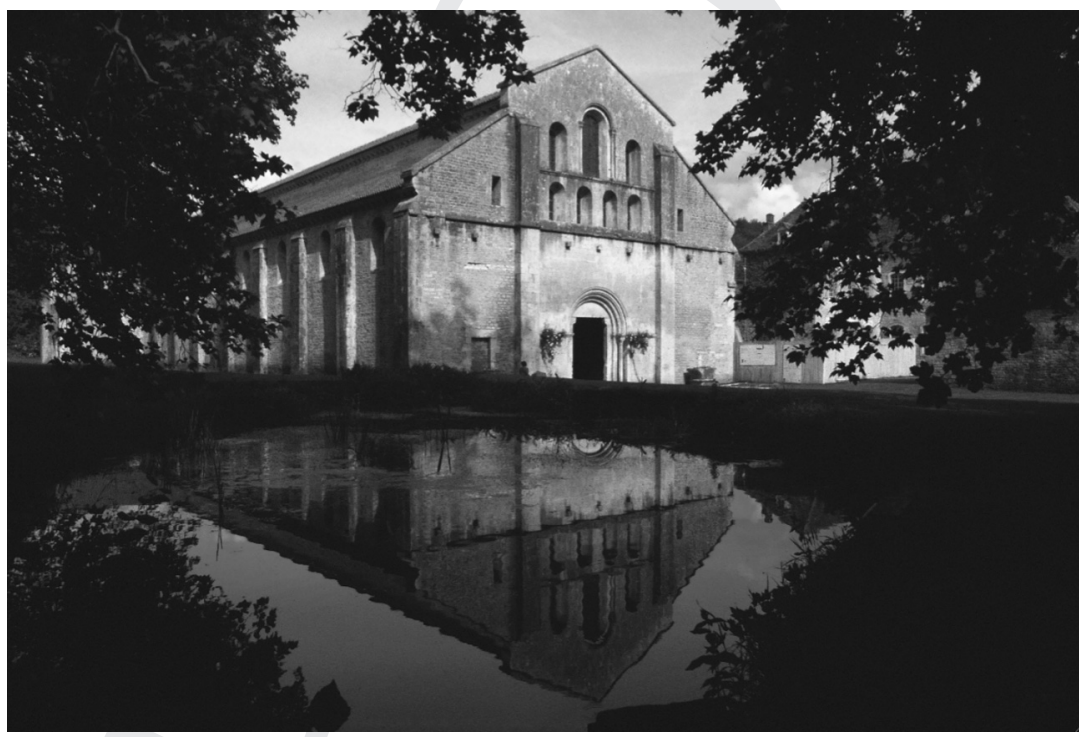

Figure I I.3 Fontenay (France), façade of the church from the west, photo: Thomas Coomans, (C) THOC-SOFAM.

music, the radical architectural norms of the Cistercians did not stifle creativity; they generated unique compositions such as the choir of Rievaulx, the rose window of Huerta, the oculus windows of Villers (Figure I I.4), the gable of Kolbacz and the apse of Heisterbach. 


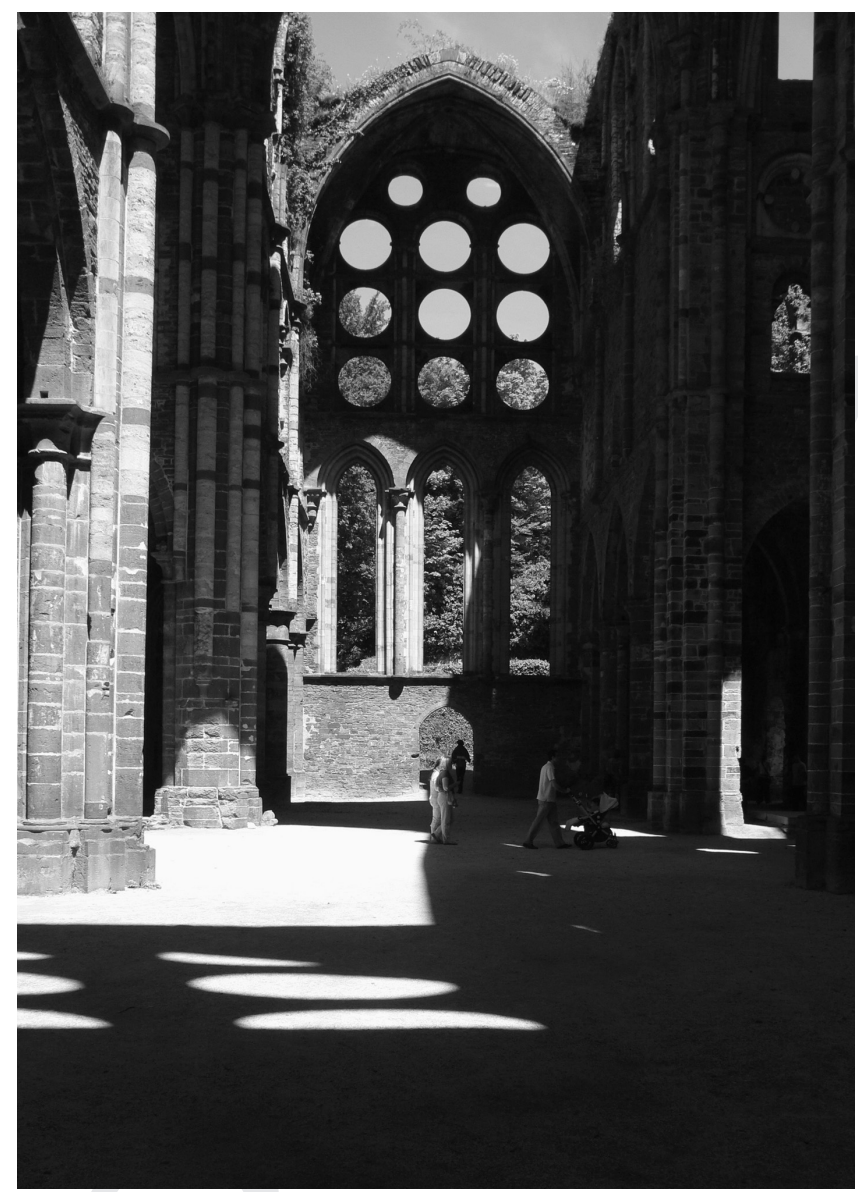

Figure I I.4 Villers (Belgium), northern transept of the church, photo: Thomas Coomans, (C) THOC-SOFAM.

In the first generations of the Order's existence a rather strict architectural church design was implemented: a nave with or without aisles, square east end and transept with two, four or more rectangular eastern chapels. This design was 'anti-Cluniac' because it lacked towers, a lantern at the crossing, crypt, rounded apses, ambulatory and radiating chapels, and was based on a square. In his famous sketchbook of around I235, Villard de Honnecourt drew the plan of a church with the caption: 'this is a church of squares as is usually made by the Order of Cîteaux' ${ }^{\prime}{ }^{23}$ In the I950s this angular design was associated with Bernard of Clairvaux because most twelfth-century churches of the Clairvaux branch did use a square east end. This plan came to be called 
'Bernardine', and the church of Fontenay (usually dated I I 39-47,,$^{24}$ thus before Bernard's death in I I 53) was seen to exemplify the 'Bernardine' prototype (Figure II.3). Even though Bernard never wrote a word on architecture, this hypothesis was attractive because of its direct connection to Bernard, as well as the institutional links that existed between a mother house and its daughter houses as defined by the Carta Caritatis. Some abbey chronicles mention converse-'architects' (lay brothers) being sent from Clairvaux to a daughter house in order to supervise the first phases of building works. As we will see, the angular or 'Bernardine' basic design could be developed on various scales and combined with different elevations and other vaulting systems as contexts and influences dictated. The angular plan did not, however, originate with the Cistercians, but it did influence the early generations of White Monks and they certainly preferred it during the twelfth century, and not only in the Clairvaux filiation. In some places it was employed as late as the thirteenth century. Such late examples, like the abbey church of Magerau in Switzerland (built in the I260s), should not be considered as anachronisms but as explicit references with a precise meaning. ${ }^{25}$

The spectacular growth of the Cistercian Order in the twelfth century not only meant the creation of 'families' of churches throughout Europe, it also motivated translations of abbeys to more appropriate sites as well as the construction of larger churches. The first abbey confronted with the need for a larger church was Clairvaux, the most powerful of the five Cistercian mother houses. Founded in I I 5 by Bernard, the first abbey was soon too small and in I I 35 a new abbey was built on another site further down the valley. After Bernard's death in I 53 the community transformed the church by building a new choir with ambulatory and radiating chapels around his tomb. Little material evidence has been preserved for any of the three churches of Clairvaux. In order to distinguish successive phases, architectural historians have used numbers; the case of Cluny I, II and III is famous, and a similar numbering system is used to distinguish the successive rebuilding of Cistercian abbey churches. Clairvaux I designates the earliest settlement, with primitive buildings and a square wooden church; Clairvaux II is the great church built under Bernard, which is considered to have included the prototypical 'Bernardine' plan; Clairvaux III is the church as transformed soon after Bernard's death. At Cîteaux, Pontigny, Fountains, Rievaulx, Vaucelles, Ourscamp in France, Villers in Belgium, Tintern in Wales and other major abbeys such phases are also distinguished by numbers (Figure I I.2. and Figure I I.5). 


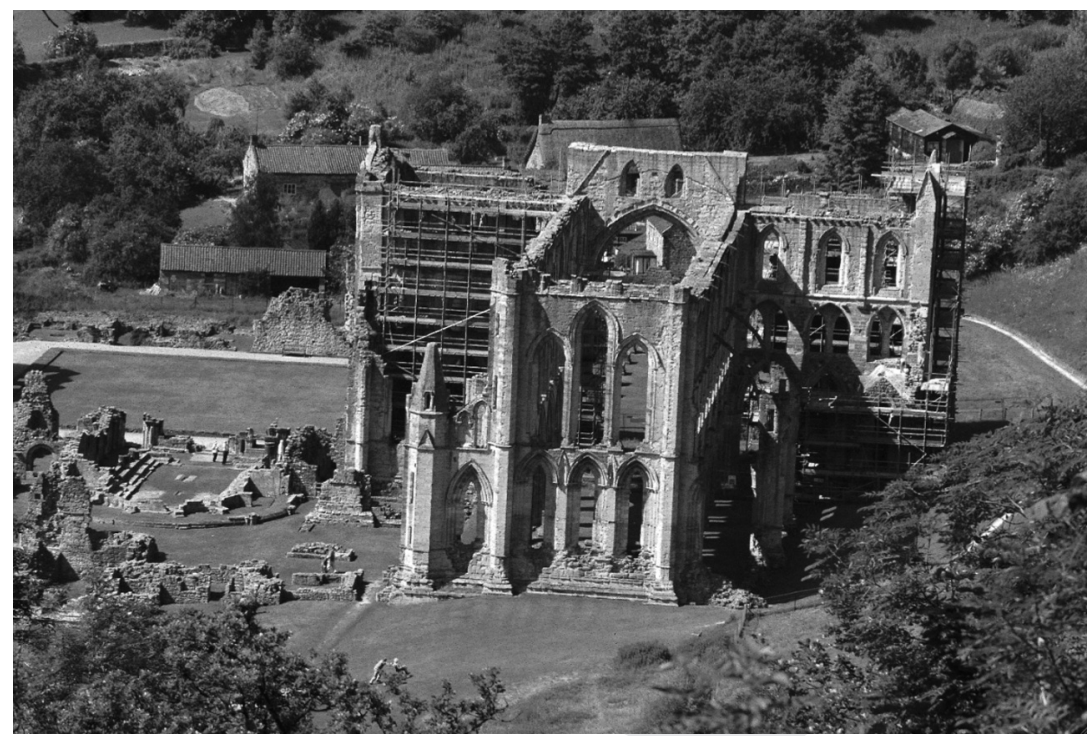

Figure I I.5 Rievaulx (England), choir and transept of the abbey church, photo: Thomas Coomans, (c) THOC-SOFAM.

From the thirteenth century on, some great abbeys adopted Gothic cathedral plans and elevations with ambulatories and radiating chapels; among the most famous are Royaumont and Longpont in France, Alcobaça in Portugal, Beaulieu in England, Altenberg in Rhineland, Sedlec in Bohemia and Doberan in northern Germany. However, other important abbeys developed original Gothic choir designs belonging to the Gothic 'avant-garde' of their time, such as the famous Chapel of Nine Altars at Fountains Abbey, the choirs of Rievaulx (Figure I I.5) and Tintern resembling huge glass shrines, or the hall-choir of Heiligenkreuz. Modifying the eastern part of the church - its light, form, scale and acoustics - had fundamental consequences for the daily liturgy, as well as for the identity of the community that was facing the choir during day and night Offices, masses and other events in the most spiritually charged part of the abbey.

The Cistercian Order would not have been as successful as it was without the support of the highest aristocracy. Not only emperors and kings, but also most dynasties of territorial princes granted the White Monks lands, privileges, exemptions, endowments and other advantages. In exchange for these material gifts, the donors expected non-material gifts from the community such as prayers for their souls and in their memory. In this context lay burial in abbey churches 
became a crucial issue, and the General Chapter had to regulate it in order to avoid an excessive increase in the number of such tombs. ${ }^{26} \mathrm{In}$ the beginning, burials in Cistercian churches were prohibited; abbots were interred in the chapter house and other religious in the cemetery. From I I57, exceptions would gradually be made for the burial of founders in the church and, from II 80, for the tombs of kings, queens and bishops in the church and cloister galleries. The General Chapter repeated this rule and sanctioned burials of dukes, counts and other aristocrats during the thirteenth century. Nevertheless, many abbey churches had become funerary churches, some of them developing specific architectural designs with crossing towers, decorated gables, westworks, ambulatories and other embellishments because of the presence of tombs and relics, for example at Poblet, Hailes, Royaumont, Chorin, Sedlec and Heiligenkreuz. From the early thirteenth century Cistercian nuns were reputed to provide the purest memorial prayers, and some of their churches - Las Huelgas Reales at Burgos, Maubuisson near Paris, Flines in Flanders, Roermond in Guelders and others - became princely necropoleis. Such buildings expressed their aristocratic status with towers, chapels and rich decoration that definitely did not conform to the forma Ordinis. From the last quarter of the thirteenth century the Cistercians opened their churches to lay burials as a consequence of a financial crisis as well as competition with the mendicants, who accepted revenues from burials in their churches. Funerary chapels with Gothic windows, stained glass and rich furnishings were erected along the sides of the nave or transept.

Around IIOO the Cistercians had begun as a reform of the Benedictines, but two centuries later it had become necessary to reform the reform. Despite the papal endeavours of 1335 Cistercian unity weakened and its identity changed. The development of regional groups of abbeys and specific congregations meant that the central authority gradually weakened. The wealthiest abbots expressed their status and autonomy with rich transformations of their churches, including bell towers (Fountains c. I 500); some abbeys built elaborate Gothic towers at the crossing (Poblet $c$. I330 and Bebenhausen in I407). Other abbots tried to reform their own houses. Because the two are often linked, it is not always easy to define whether late medieval modernisations are a matter of pure prestige or expressions of reform. Changing the shape of the choir or enlarging windows, building new stalls and erecting an elaborate high altar seem to have been common methods used to reform a community, or at least to mobilise the monks around a project and so develop a new dynamic. A well-preserved example can 
be seen at Maulbronn, where, in the middle of the fifteenth century, the Romanesque eastern wall of the sanctuary was pierced with a window of Gothic tracery and new stalls were built in the choir. In other cases the whole eastern end was rebuilt, such as at Melrose in I390 and Furness in the late fifteenth century.

Some authors check individual Cistercian buildings against the 'Bernardine' canon in order to see how they conform to it and thus how 'Cistercian' they are. If the building does not fit in with the expected forma Ordinis, it is considered less valuable or even 'decadent'. Such interpretations are misguided because they are not driven by an interest in unravelling the cultural and historical meaning of individual buildings in their unique contexts. Even though the striving for an architectural identity was evident during the first century, right from the beginning the expressions were diverse, depending on the evolving geographical and historical contexts.

The permanent tensions between the strong centralised structure of the General Chapter - a guarantor of tradition and unity - and the diversity of local conditions generated an original dynamic that explains both the common identity and the multiple specificities of Cistercian architecture. ${ }^{27}$ The buildings, especially churches, should be understood as having been shaped by the interaction between three different levels at a precise moment. The first, or international, level is the Cistercian Order with its norms, legislation, liturgy and forma Ordinis, including an aesthetic dimension. This level is common to all Cistercian abbeys and expresses the identity of the Order as an institution. The second level is regional; the patrons or decision makers: the abbot with his community, his mother house and the regional networks supporting the abbey, including the nobility and the bishops. Some abbots had previously lived in another abbey and therefore chose that as their model. The influence of the burial of founders and other benefactors on the design of the abbey also belongs to this level. The third level is local: the builders, masons, carpenters and other workers and craftsmen using local building materials to give physical form to the project. It should be said here that the legends of monks building their own church and transmitting building secrets is a Romantic myth. As explained above, there were sometimes teams of specialised lay brothers acting as master masons or foremen who gave directions to lay workers, but monks were expected to pray and not carve stone or make mortar. Monk or layman, the master or 'architect' had to synthesise the influences of these three levels when he designed a project and translated the complex identity of a group into form, matter and structure. 


\section{ARCHITECTURE AS MATERIAL SOURCE FOR MONASTIC LIFE}

Abbeys are much more than churches; they are enclosed building complexes organised around cloisters and courtyards. Community life according to a religious belief, a rule and vows implied strict organisation. Centuries of experience defined the daily life of the monk or nun as well as all other religious and lay people living in specific parts of the abbey (conversi, novices, sick and elderly monks, guests, servants, farmers and seasonal workers). Again, the Cistercians followed a long tradition, modifying some aspects as appropriate to their time and location. The Ecclesiastica officia, a Cistercian book of customs from the twelfth century, ${ }^{28}$ contains I 2 I chapters with precise information on the way in which behaviour, liturgy, rituals, feasts and work were to be performed in the church, cloister, chapter house, dormitory and other common rooms. This exceptional source defined the theoretical and spiritual aspects of the services that monks practised in the gatehouse, refectory, kitchen, infirmary, guesthouse, storeroom, sacristy and the novices' house.

Scholars have combined material evidence from the monastic buildings surrounding the cloister with written and visual sources - including the instructions in the Ecclesiastica officia - to define a 'Cistercian model plan' that became commonplace in most publications about the White Monks. The symbolically and liturgically charged east-west orientation of the church determined the development of the rest of the complex. The cloister forms a central square (Figure I I.6), surrounded by four galleries flanking the church to the north, the monks' wing to the east, the lay-brothers' wing to the west and the refectory wing to the south. In each wing the rooms follow a predictable succession. The monks' range to the east included the sacristy, book cupboard (armarium), chapter house, parlour, monks' room (sometimes scriptorium) and the day-stairs leading to the monks' dormitory on the first floor. The building opposite the church consists of a warming room (calefactorium) and kitchen, each with chimneys, flanking the refectory; close to the entrance of the latter in the cloister garth is the fountain (lavatorium). The lay-brothers' range is sometimes, but not systematically, separated from the cloister by an open space called a 'lay-brothers' lane'; the building contains a storeroom and lay-brothers' refectory on the ground floor and a dormitory on the upper floor (Figure I I.7 and Figure I I.8). The dormitories of both monks and lay brothers are connected to the church to facilitate access for night prayers, with a latrine block (the 'reredorter') on the opposite side. 


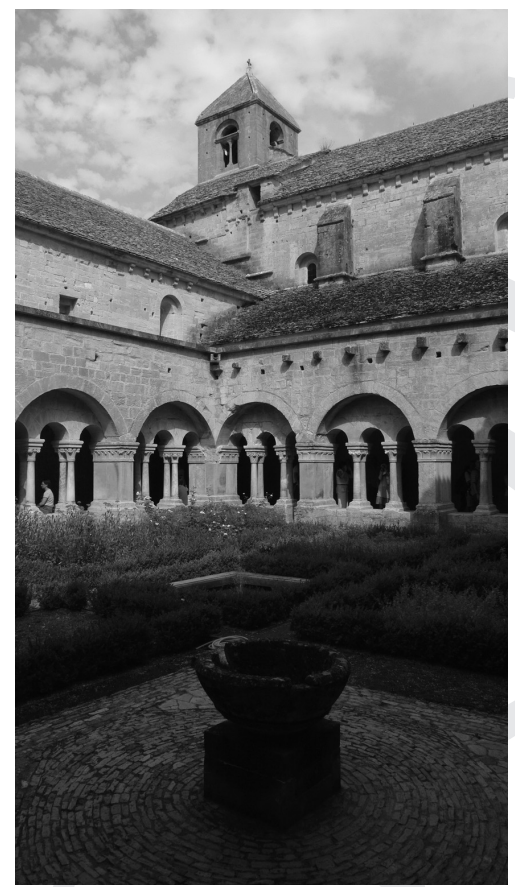

Figure I I.6 Sénanque (France), cloister and church, photo: Thomas Coomans, (C) THOC-SOFAM.

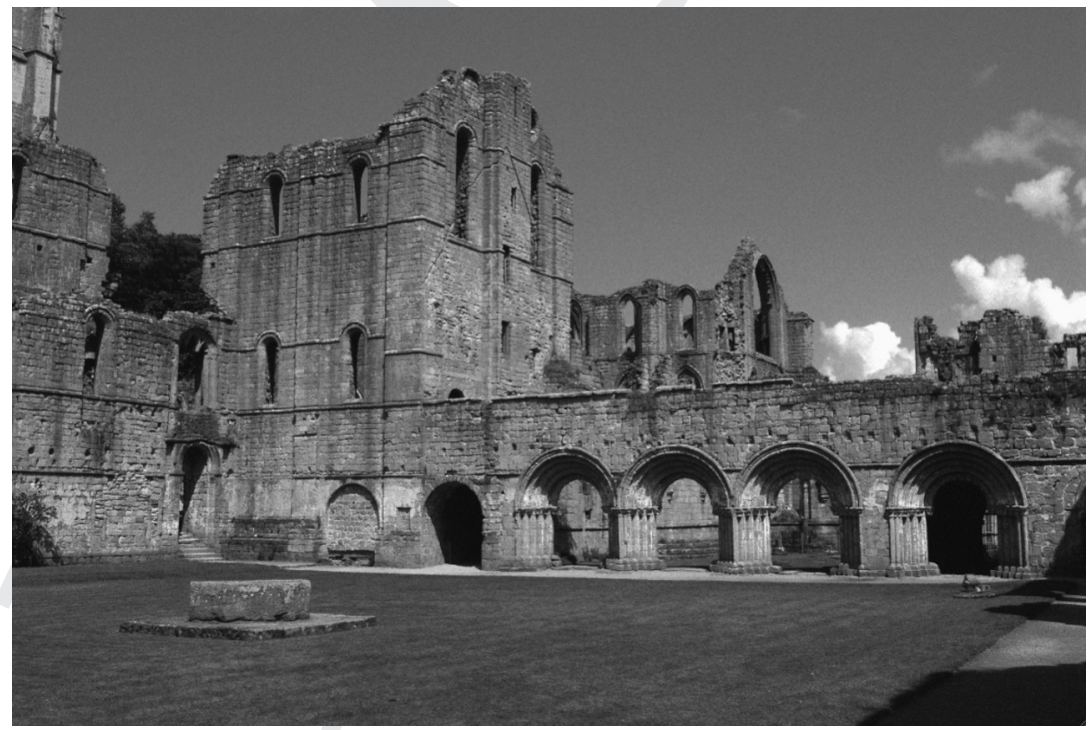

Figure I I.7 Fountains (England), chapter house and southern transept of the church, photo: Thomas Coomans, (C) THOC-SOFAM. 


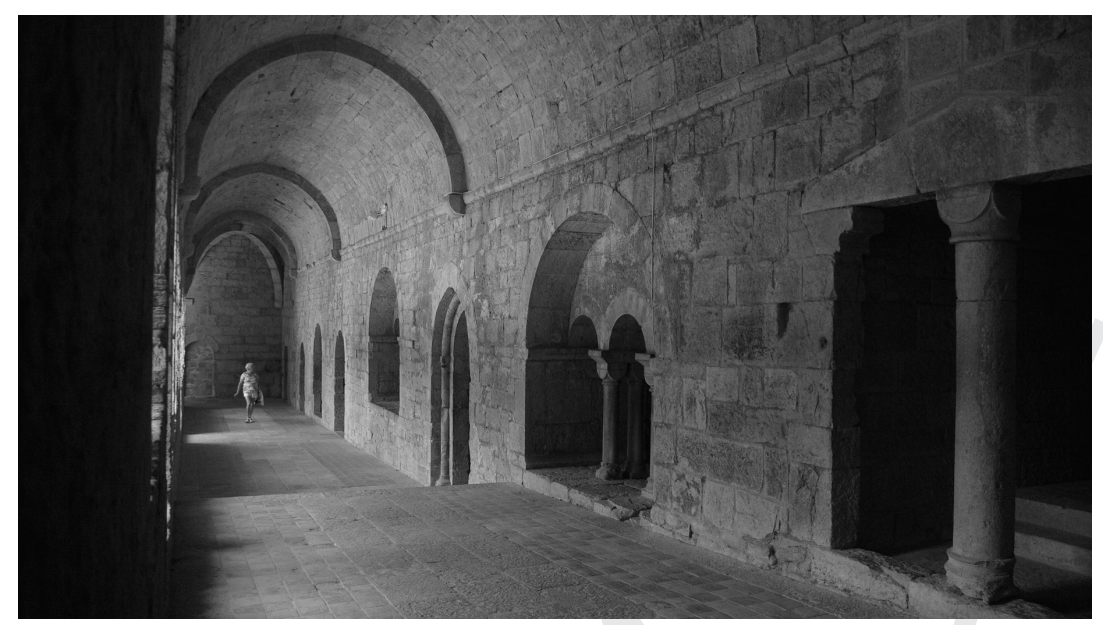

Figure II.8 Le Thoronet (France), eastern gallery of the cloister, photo: Thomas Coomans, (C) THOC-SOFAM.

This functional model has been enhanced by nineteenth-century rationalism that defined standardised designs for all building types, especially for communities (schools, prisons, barracks, convents and so on). Recent developments in archaeology, construction history, hydrology, landscape history and other aspects of material culture seriously challenge this theory and invite something more nuanced than the simplistic idea of a 'model Cistercian plan'. The first consideration is the influence of the topography on the choice of site and general design of the abbey. Most abbeys are situated in valleys, with the church at the highest point and the water supply close to the kitchen and refectory, but they also needed ponds, mills and other workshops. Hydraulic systems were created to include ingenious networks of pipes and sewers which differ from abbey to abbey according to location, the size of the community and its economic activity. The second consideration is that an abbey cannot be reduced to a church and monastic buildings around the cloister. Abbeys were self-sustaining institutions that also needed areas for production and storage. The 'model plan' ignores indispensable structures such as the abbot's house, infirmaries for monks and lay brothers, guesthouse, ancillary buildings and the home grange and stables. Pioneering work by Glyn Coppack on the abbey precincts of Rievaulx and Fountains in Yorkshire has distinguished inner and outer courts for specific activities, accessible to specific groups of people whose circulation was controlled by several inner and outer gatehouses. ${ }^{29}$ This complex spatial organisation was adapted to each abbey, as has been 
shown in other case studies. ${ }^{30}$ The third consideration is that abbeys had to modify their buildings in response to constantly evolving factors which differed from abbey to abbey and resulted in a variety of architectural solutions. For example, the reduction or disappearance of the conversi from the mid thirteenth century led to the reuse of their buildings; the development of privacy from the fourteenth century resulted in the partition of common dormitories and infirmary halls into individual cubicles and later into separate rooms; ${ }^{3 \mathrm{I}}$ the size of some communities as well as their income was sometimes so dramatically reduced that whole buildings, including unused parts of churches, were demolished. Yet another consideration is that each abbey was the centre of a domain, sometimes tens of thousands of acres in extent, that developed a wide range of types of forestry as well as agro-pastoral and pre-industrial economies. Buildings were spread over the domain, organised in specialised units or granges, with barns, mills, stables and forges, and also urban cellars for selling goods at markets. ${ }^{32}$

The confrontation of the theoretical monastic 'model plan' with several hundred preserved or excavated abbeys does reveal some similarities, at least enough to allow us to recognise a 'family resemblance'. Once again, however, a huge gap between 'ideal and reality' becomes evident, all the more since the 'ideal' in question comes from nineteenth-century scholars rather than medieval monks. Since current archaeology not only brings walls to light and follows them in order to reveal plans - as in William St John Hope's time - but also analyses contexts, material traces and artefacts with the help of natural science, the reality is much more complex than the theory and may perhaps be more human than the ideal(s).

\section{RESEARCH PERSPECTIVES}

The current challenge to Cistercian studies - including architecture, which comprises the best material evidence - is to extend the scope of the enquiry by looking beyond medieval Cistercian life. This challenge implies multidisciplinary investigation combined with other historical sciences and methods. Three main research perspectives are beginning to broaden the field: Cistercian architecture after the Middle Ages, Cistercian women's houses and monasteries of other religious Orders.

Because the twelfth and thirteenth centuries are the most spectacular phase of Cistercian history, development and institutional unity, these centuries unfairly eclipse the rest of the Order's history, including the present. The changes in administration after I335, attempts at 
reform in the fifteenth century, suppression of all abbeys in Protestant countries (England, Holland, Scandinavia, northern Germany) during the first half of the sixteenth century, systematic imposition of commendatory abbots, the Strict Observance reform in the seventeenth century, massive suppressions of abbeys during the French Revolution (France, Belgium, Germany, Italy) or under early nineteenth-century liberal governments (Portugal, Spain, Switzerland) and then monastic revival and world-wide expansion in the twentieth century are fascinating chapters of Western monastic history that also include architectural transformations. Some abbeys were destroyed; others received new architectural layers in the dominant style of the time: late Gothic (Figure I I.9), Renaissance, Baroque, Rococo, Classical, Gothic revival or modern. Where monastic life was abandoned, abbeys (or parts of them) were recycled as prisons, factories or mansions; other monastic ruins were restored and maintained, and sometimes abbeys were even refounded on old sites - though none of this is unique to the Cistercians. In any case, one might ask how Cistercians redefined their architectural identity and transformed their monasteries? Were the White Monks aware of architectural specificity or symbolism inherent in the buildings? From this point of view, the nineteenth century is a crucial period because architecture was not a major issue for the (Cistercian) Trappists. Only when scholars began to define medieval Cistercian architecture as a 'style' would modern Cistercians claim it as a part of their legacy. ${ }^{33}$ From the early twentieth century, this 'rediscovered architectural identity' became a reference for foundations such as Orval (I926).

Because the female branch of the Cistercian Order was not part of the original project and did not develop significantly before the thirteenth century, its history was long ignored or neglected. Compared with the architecture of the men's abbeys, nunneries were often considered 'simple' and therefore less relevant, ignoring the conditions under which the women often struggled to achieve and maintain Cistercian identity in a male-dominated culture. Architectural and historical interest in women's houses is recent and still limited to the Middle Ages. ${ }^{34}$ Pioneering archaeological work of Roberta Gilchrist on houses of religious women developed a gender approach to space, enclosure, architecture and other aspects of material culture, without positing a difference between Cistercian women and those of other Orders. ${ }^{35}$ From an art historical point of view, recent work coordinated by Jeffrey Hamburger and Suzan Marti questions the relationship between objects and liturgical space in medieval women's monasteries. ${ }^{36}$ In this regard, the exceptionally well-preserved medieval interiors of the Cistercian 


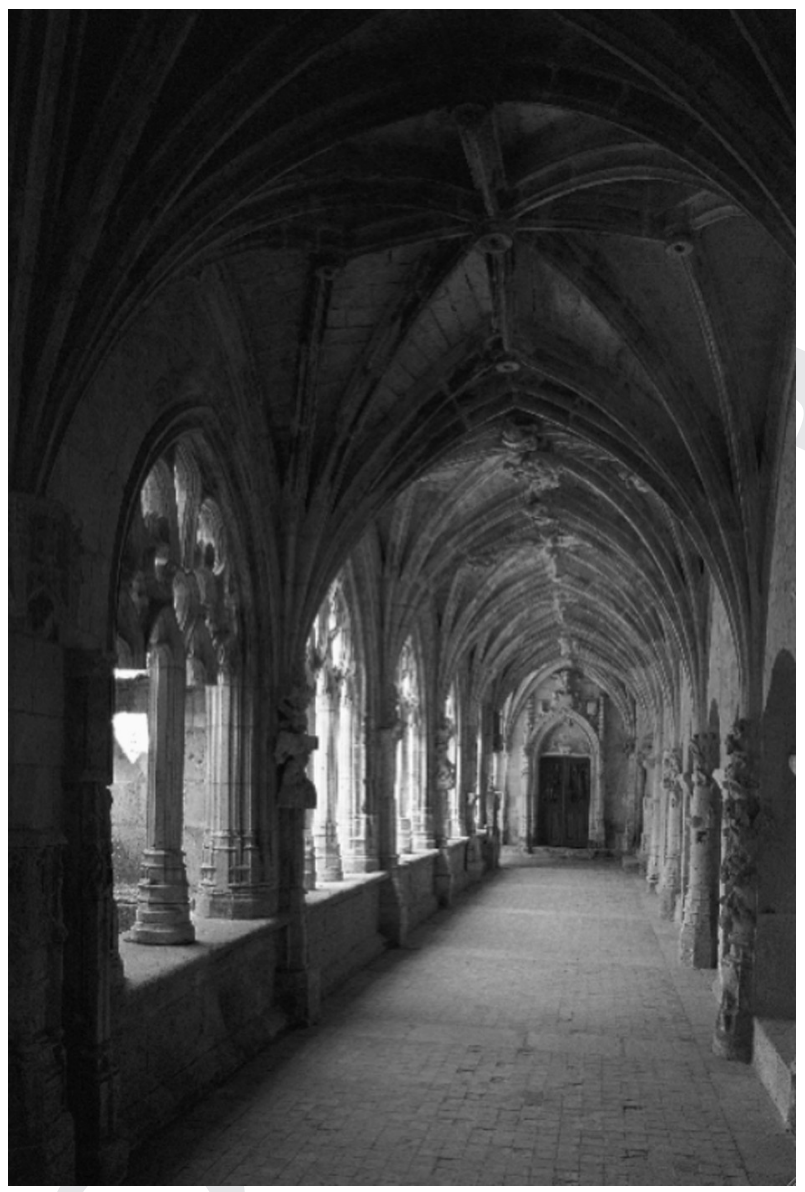

Figure I I.9 Caduin (France), late medieval cloister gallery, photo: Thomas Coomans, (c) THOC-SOFAM.

nunneries of Wienhausen and Magerau provide fascinating evidence. Such approaches should be expanded to post-medieval times, especially the seventeenth-century Counter-Reformation and the monastic revival of the nineteenth century.

Only the combination of a diachronic approach to Cistercian architecture through the centuries and a synchronic approach which juxtaposes contemporaneous components of monasticism is able to reveal the variety and the identity of the Order's architecture. Therefore it would be more appropriate to speak about the architecture of the Cistercians than about Cistercian architecture. It is true that there seems to have been an architectural canon in the twelfth century, defined as forma 
Ordinis. Yet the idea that there was a 'Cistercian architecture' rests on the assumption that all Cistercian buildings had to follow a standardised programme with strict rules about style, whereas 'the architecture of the Cistercians' insists, more correctly, on the diverse and evolving architectural identity of the White Monks across more than nine centuries.

\section{Notes}

I Fontenay (I98I), Fountains (I986), Alcobaça (I989), Poblet (I99I) and Maulbronn (I993).

2 E.E. Viollet-le-Duc, Dictionnaire raisonné de l'architecture française du XIe au XVIe siècle, Io vols. (Paris, I 854-68).

3 E. Sharpe, The Architecture of the Cistercians, 2 vols. (London, I874).

4 C. Enlart, Origines françaises de l'architecture gothique en Italie (Paris, I 894).

5 G. Dehio and G. von Bezold, Kirchliche Baukunst des Abendlandes, 2 vols. (Stuttgart, I 887-I901).

6 G. Coppack, Book of Abbeys and Priories (London, I990), pp. 22-3 I.

7 Most Cistercian journals were begun by monks and supported by abbeys: Cistercienser Chronik I889; Collectanea Cisterciensia I934; Analecta Cisterciensia I945; Cistercium: Revista monastica cisterciense I948; Cîteaux: Commentarii cistercienses I950; Cistercian Studies Quarterly I966; Rivista Cisterciense I984.

8 M. Aubert and A. de Maillé, L'architecture cistercienne en France, 2 vols. (Paris, I 943).

9 K.-H. Esser, 'Les fouilles à Himmerod et le plan bernardin', Mélanges Saint Bernard (Dijon, I953), pp. 3II-I5; H.-P. Eydoux, 'Les fouilles de l'abbatiale d'Himmerod et la notion d'un plan bernardin', Bulletin monumental, I I I (I953), 29-36; H. Hahn, Die frühe Kirchenbaukunst der Zisterzienser: Untersuchungen zur Baugeschichte von Kloster Eberbach im Rheingau und ihren europäischen Analogien im I2. Jahrhundert (Berlin, I957).

Io A. Dimier, Recueil de plans d'églises cisterciennes, 2 vols. (Grignan and Paris, I949-67); A. Dimier, L'art cistercien (Saint-Léger-Vauban, I962); A. Dimier, L'art cistercien hors de France (Saint-Léger-Vauban, I97I); G. Duby, Saint Bernard: l'art cistercien (Paris, 1976).

I I F. Pouillon, Les pierres sauvages (Paris, I964); F. van der Meer, Atlas de l'ordre cistercien (Paris and Brussels, I965); F. Cali, L'ordre cistercien d'après les trois sœurs provençales, Sénanque, Silvacane, le Thoronet (Paris, 1972).

I 2 K. Elm, P. Joerissen and H.J. Roth (eds.), Die Zisterzienser: Ordensleben zwischen Ideal und Wirklichkeit, 2 vols. (Cologne, I980-2); L. Pressouyre and T. Kinder (eds.), Saint Bernard et le monde cistercien (Paris, I990).

I3 By Cistercian Publications (Kalamazoo, MI), vols. I-VI (I982-2005), ed. M.P. Lillich. 
I4 C.A. Bruzelius, 'Cistercian High Gothic: The Abbey Church of Longpont and the Architecture of the Cistercians in the Early Thirteenth Century', Analecta Cisterciensia, 35 (I979), 3-204.

I5 L. Pressouyre (ed.), L'espace cistercien (Paris, I994).

I6 L. Pressouyre and P. Benoit (eds.), L'hydraulique monastique: milieu, réseaux, usages (Paris, I996).

I7 C. Norton and D. Park (eds.), Cistercian Art and Architecture in the British Isles (Cambridge, I986); P. Fergusson, Architecture of Solitude: Cistercian Abbeys in Twelfth-Century England (Princeton, NJ, I984); R. Stalley, Cistercian Monasteries of Ireland (New Haven, CT and London, I987); G. Coppack, The White Monks: The Cistercians in Britain II28-I540 (Stroud, I998); G.G. Astill, 'The Bordesley Abbey Granges Project', in L'espace cistercien, ed. Pressouyre, pp. 537-53; D. Robinson, The Cistercians in Wales: Architecture and Archaeology, I I30-I 540 (London, 2005).

I8 For example M. Plouvier and A. Saint-Denis (eds.), Pour une histoire monumentale de l'abbaye de Cîteaux I098-1998, Cîteaux: Studia et Documenta 8 (Vitreux, I998); G. Coppack, Book of Fountains Abbey (London, I993); P. Fergusson and S. Harrison, Rievaulx Abbey: Community, Architecture, Memory (New Haven, CT and London, I999); T. Coomans, L'abbaye de Villers-en-Brabant: construction, configuration et signification d'une abbaye cistercienne gothique (Brussels, 200o); C. Kratzke, Das Zisterzienserkloster Dargun in Mecklenburg-Vorpommern: Studien zur Bau- und Kunstgeschichte (Petersberg, 2004).

I9 M. Hörsch, 'Tendenzen der Zisterzienser-Literatur der letzten zehn Jahre unter besonderer Berücksichtigung kunsthistorischer Studien zu den Ordensklöstern in Mitteleuropa', Cîteaux, 58 (2007), I 3 I-70.

20 T.N. Kinder, Cistercian Europe: Architecture of Contemplation (Grand Rapids, MI, 2002); M. Untermann, Forma Ordinis: Die mittelalterliche Baukunst der Zisterzienser (Munich and Berlin, 200I).

2 I M. Cassidy-Welch, Monastic Spaces and Their Meanings: Thirteenth-Century English Cistercian Monasteries (Turnhout, 2001).

22 C. Norton, 'Table of Cistercian Legislation on Art and Architecture', in Cistercian Art and Architecture in the British Isles, ed. Norton and Park, pp. 3 I 5-93.

23 Paris, Bibliothèque nationale, MS fr. I9093, fol. I4v: 'vesci une glize desquarie ki fu esgardee a faire en lordene dcistiaus'.

24 This dating has been contested recently. The church seems to have been completed in the I I6os, after Bernard's death; S. Harrison, 'Dating the Abbey Church of Fontenay: A Reassessment of the Evidence', Cîteaux, 6I (2010), 99-I24.

25 S. Gasser, 'Die Zisterzienserinnenkirche in der Magerau: Retrospektive Architektur als Trägerin ordenspolitischer Intentionen', Zeitschrift für Schweizerische Archäologie und Kunstgeschichte, 54 (2001), 259-66.

26 J. Hall and C. Kratzke (eds.), Sepulturae cistercienses: Burial, Memorial and Patronage in Medieval Cistercian Monasteries, thematic issue of Cîteaux, 56 (2005). 
27 Untermann, Forma Ordinis.

28 Choisselet/Vernet.

29 Coppack, Book of Fountains Abbey, pp. 8I-I28.

30 Coomans, L'abbaye de Villers-en-Brabant, pp. 43 I-542.

3 I D.N. Bell, 'Chambers, Cells, and Cubicles: The Cistercian General Chapter and the Development of the Private Room', in Perspectives for an Architecture of Solitude: Essays on Cistercians, Art and Architecture in Honour of Peter Fergusson, ed. T.N. Kinder (Turnhout, 2004), pp. I $87-98$.

32 F. Blary, Le domaine de Chaalis, approches archéologiques des établissements agricoles et industriels d'une abbaye cistercienne (Paris, I998; first pub. I989).

33 T. Coomans, 'La ricerca di una nuova identità nell'architettura cisterciense del XIX secolo', in Arte Cisterciense, ed. T.N. Kinder and R. Cassanelli (Milan, in press).

34 For example, M.P. Lillich (ed.), Cistercian Nuns and Their World, Studies in Cistercian Art and Architecture 6 (Kalamazoo, MI, 2005).

35 R. Gilchrist, Gender and Material Culture: The Archaeology of Religious Women (London, I994).

36 J.F. Hamburger and S. Marti (eds.), Crown and Veil: The Art of Female Monasticism in the Middle Ages (Columbia, NY, 2008). 
